\title{
Demography of Degenerative Arthropathy and Regenerative Medicine in Santiaguero Sport
}

\author{
CrossMark \\ Viviana Romero Vidala, Niurka Aurora Ali Pérez ${ }^{\mathrm{b}}$, Rosa Julia Robinson Rodríguezc, \\ Karenia León Munive ${ }^{\mathrm{d}}$
}

Manuscript submitted: 27 August 2020, Manuscript revised: 18 September 2020, Accepted for publication: 09 October 2020

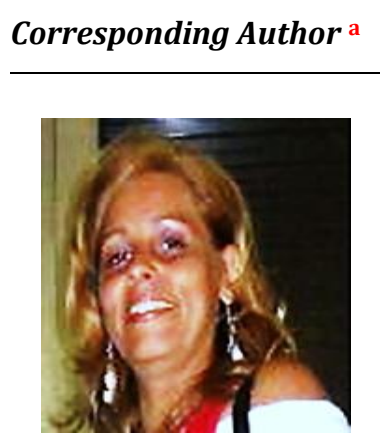

Keywords

arthropathy;

degenerative;

regenerative medicine;

sports injury;

steoarthrosis;

\begin{abstract}
This research uses regenerative medicine in degenerative arthropathy for sport, intending to demographically evaluate this population, general variables, and individuals of interest were assessed. In the percentage statistical analysis for the interpretation of results was obtained from the general variables, the predominance for males in the group of former athletes in the age range of 41 to 50 years, grade II of knee ostearthrosis as the region of anatomical location, and the most affected degree, the time of manifestation of the disease the eldest of the year of evolution, the over-use as an incidence factor for the onset of injury in the group of most affected sports treated, and as a treatment of implanted regenerative medicine most employed platelet-rich plasma (PRP). In particular variables of interest, the predominance in training, and the training cycle for the occurrence of the injury, and the competitive stage for athletes, and the general stage for former athletes, was obtained from the location for the occurrence of the injury.
\end{abstract}

\section{Contents}

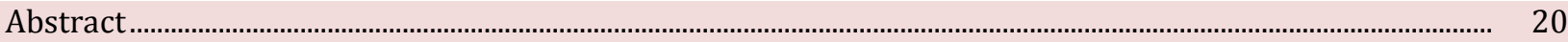

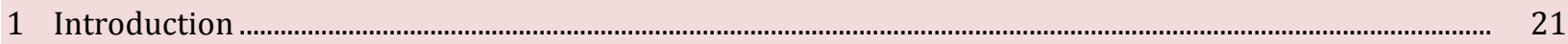

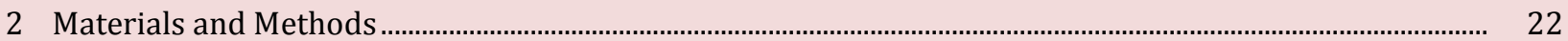

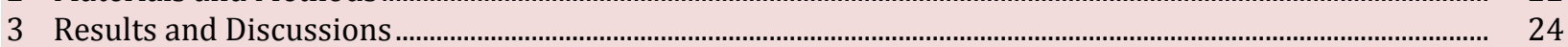

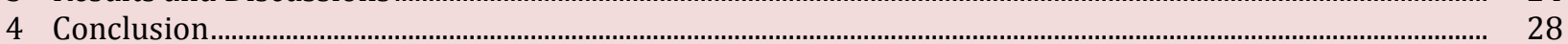

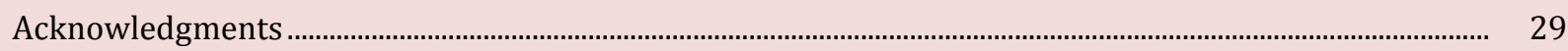

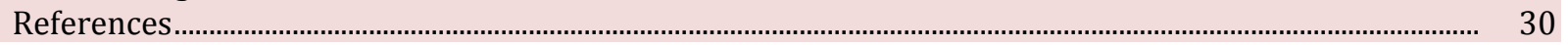

a Centro Provincial de Medicina Deportiva (CEPROMEDE), Santiago de Cuba, Cuba

b Banco de Sangre Provincial, Santiago de Cuba, Cuba

c Universidad de Ciencias Médicas. Facultad de Medicina No. 2 Santiago de Cuba, Cuba

d Banco de Sangre Provincial, Santiago de Cuba, Cuba 


\section{Introduction}

Joint injuries caused by sports practice cause the appearance of degenerative arthropathies, including, ostearthrosis, which is frequently treated in our environment. It is known that, from medical notions, the soft tissues of the osteomyoarticular system represent the greatest number of components of the human body, they form the large family of connective tissues, of them: the synovial capsule and ligaments that surround as a resistant mantle the joints stabilizing them, the synovial membranes or bursas that secretes the joint fluid, cartilage that coats the ends of the bones that make it up, it is these tissues that, when damaged by intense sporting activity, condition the appearance of degenerative diseases such as ostearthrosis (Alvarez et al., 2004).

At the age of $60 \%$ of the lesions in sport correspond to the soft tissues of the osteomioarticular system that lead to the onset of degenerative joint diseases, of which between 40 and $50 \%$ have their origin the chronic lesions of slower development, since they are caused by the repetition of the same movement over a long period, as is in the overuse of the joint, (repetitive microtrauma), another percent is caused by acute traumas that occur suddenly, either during their training or fundamental competence being in sport causes that condition the appearance of joint degenerative diseases among them the entity of osteoarthritis (Alvarez et al., 2004; Garrick, 2017; Martinez, 2017).

The most commonly used definition of osteoarthritis corresponds to that developed by the American Academy of Orthopaedic Surgeons and the National Institutes of Health in 1994: "Arthrotic diseases are the result of mechanical and biological events that destabilize the normal coupling between degradation and synthesis of joint cartilage chondrocytes and extracellular matrix, and subchondral bone. In the end, arthrotic diseases are manifested by morphological alterations, biochemical, molecular and biomechanical cells and matrix leading to softening, fibrillation, ulceration, loss of joint cartilage, sclerosis and ossification of subchondral bone, osteophytes and subchondral cysts" (Keuttner \& Goldberg, 1995; Martinez, 2015).

According to De los Santos (2009), sports injuries are the various ways in which an athlete's body can be affected in a given discipline during the different stages of the training macrocycle or their fundamental competition. It is supported by the expert because due to the characteristics of the different sports groups (combat, fast force, time and brand, games with balls and competitive art) constitute a Problem especially for athletes of high performance (Alvarez-Cambras et al., 2014).

Predisposing factors make the athlete more susceptible to injury, stress, poor joint flexibility or elasticity, inadequate warm-up, insufficient stretching, poorly dosed training loads or overloads, inadequate work-rest regimen, overuse of the joint, poor technique, incorrect use of sports equipment, bad eating habits, poor condition of training areas, inappropriate climate, acute trauma, history of the previous injury, among others (Garrick, 2017; Finch, 2006; Ahern \& Lohr, 1997).

In Cuba, multiple promising results have been published in traumatic and orthopedic alterations in the conventional population, and in sports injuries with the application of regenerative therapy in degenerative arthropathies and other causes (Hernández \& Anillo, 2016; Abad et al., 2020). In the Blood Bank of Santiago de Cuba, the Regenerative Medicine Outpatient Service (SAMERSAC) was created, where mononuclear cell products and autologous platelet derivatives are obtained with the maximum guarantee of their quality, safety, efficacy, and efficiency (MINSAP, 2012; Ali et al., 2019), which allows research to be carried out with the application of regenerative therapy.

The objective of the research is to characterize the demographic incidence of degenerative arthropathy in the population under the study of the sports community of Santiago de Cuba for the application of regenerative medicine with cell therapy.

Vidal, V. R., Pérez, N. A. A., Rodríguez, R. J. R., \& Munive, K. L. (2020). Demography of degenerative arthropathy and regenerative medicine in santiaguero sport. International Journal of Health Sciences, 4(3), 20-31. https://doi.org/10.29332/ijhs.v4n3.457 


\section{Materials and Methods}

A descriptive study was carried out in the population under the study of the sports community of Santiago de Cuba, carrier of degenerative arthropathy for the application of regenerative medicine with cell therapy (Zuckerman et al., 2000; Rhee et al., 2004). The general and particular demographic variables of interest in the research were described. For this, we started from the data collected from the medical records made up by the author in the investigation, the percentage statistical analysis was used for the interpretation of the results.

The patients were distributed according to demographic variables:

General variables evaluated:

Age: it was distributed in a discrete quantitative way in completed years and was presented using scales or ranges of intervals. Table 1.

18 - 30 years

$31-40$ years

41-50 years

51-70 years

Sex: it was registered in a dichotomous nominal way according to the biological sex of belonging. Table 1 .

Male

Female

Group: it was distributed according to the athlete active in the sport for the athlete, and the non-active athlete or retired from the sport for the former athlete. Both of the High Performance. table 1.

Athletes

Former athlete

Anatomical location: it was distributed according to the region of the affected joint. table 1.

Shoulders

Knees

Degree of osteoarthritis: by Kellgren and Lawrence scale (Kellgren \& Lawrence, 1957), which evaluates the degrees of osteoarthritis observed on x-rays. The following degrees were recorded according to the anatomical location of the injury area (shoulders and knees) for both. Table 1.

Osteoarthrosis Grade 0: (Normal).

Osteoarthrosis Grade I: (Doubtful): it impresses minimal narrowing of the joint space.

Osteoarthrosis Grade II: (Mild): narrowing of the joint space, osteophytes.

Osteoarthrosis Grade III: (Moderate): joint space narrowing, osteophytes, mild sclerosis, possible deformity of the ends of the bone.

Osteoarthrosis Grade IV: (Severe): marked narrowing of the joint space, abundant osteophytes, severe sclerosis, deformity of the ends of the bone.

Sports group: it was distributed according to the sports group that practiced in the following categories. Table 1.

Combat

Quick strength and speed

Time and brand

Ball games

Competitive art

Time of evolution of the disease: it was distributed quantitatively in evolutionary months of manifestation of the symptoms of the disease, and it was presented in ranges of intervals. Table 1. 
$<3$ months

4 - 6 months

7 - 1 year

$>1$ year

Incidence factors in the appearance of the lesion: it was recorded according to the prevalence of appearance in the degenerative lesion. Table 1.

Poorly dosed training loads. Overload

Previous injury history

Overuse

Acute sports trauma

Implanted cell therapy: it was recorded according to the classification of the type of regenerative medicine cell product received by patients in the implanted lesion area (anatomical location). Table 1.

PRP (Platelet Rich Plasma)

CMN - SP (Peripheral Blood Mononuclear Cells)

Reimplantation: it was recorded according to the cell product that patients received in the implanted lesion area one year after the last implantation of the previous treatment, such as another cycle or new treatment, in patients who showed evidence of partial favorable results or loss of positive responses reached. Table 1.

PRP (Platelet Rich Plasma)

CMN - SP (Peripheral Blood Mononuclear Cells).

Particular variables evaluated:

I. When the injury occurs. Table 2. It was recorded for athletes and former athletes during and after active sports life, it was distributed in the following categories:

Athletes (high performance):

Athlete Location:

EIDE: Sports Initiation School

Academy

Pre national team

National selection

Sports combined

University of Physical Culture

The occurrence of injury:

Training

Caps or provincial games

National games

Panamerican Games

Olympic Games

Hiring abroad

\section{a) (Former athletes)}

Former Athlete Location:

During active sports life

Injury occurrence:

Training

Provincial stops or games

National games

Pan American games

Olympic Games

Vidal, V. R., Pérez, N. A. A., Rodríguez, R. J. R., \& Munive, K. L. (2020). Demography of degenerative arthropathy and regenerative medicine in santiaguero sport. International Journal of Health Sciences, 4(3), $20-31$. https://doi.org/10.29332/ijhs.v4n3.457 
Overseas recruitment

Former Athlete Location:

Post sports active life

Injury occurrence:

Detraining

Other

II. Training cycles in which the injury occurs. Table 3. It was registered for athletes, and former athletes during and post-active sports life was distributed in the following categories.

a) Training cycles:

(1st stage) and general physical preparation cap: the greatest amount of load is applied to the athlete i.e. higher volumes, of strength and resistance aerobic and anaerobic.

(2nd stage) and special physical preparation cover: already achieved the capacity of volumes of loads demanded by each sport at this stage works mostly the technical skills - tactical to maintain what has been achieved in the previous stage in terms of physical needs.

(3ra stage) and competitive physical preparation cap: consists of the following:

- (Pre-competitive): it is the modeling of the athlete that he will face the competition.

- (Competitive): it is already the competition for which the athlete was prepared throughout the year.

- (Transit): decrease of the loads acquired until reaching a level similar to the beginning of the (1st stage).

b) Don't ciclos

\section{Results and Discussions}

Table 1 shows the distribution of patients according to the results of the general demographic variables of interest.

Of the total population of 13 athletes treated with regenerative therapy, the predominate was for males in those of the group of patient's former athletes in the age range of 41 to 50 years with $23 \%$.

Consulted bibliography De Los Santos (2009), refers to that osteoarthritis is more common in women, and occurs at an early age of 45 years, and in high-yielding females even younger. Not coinciding with our results in terms of sex, yes in the age group, we thought that the predominance we obtained for the male over the female, is because it was these who assisted the most for the treatment of regenerative therapy in osteoarthritis.

The study obtained in terms of anatomical location the region most affected by the degenerative injury of steatosis knees at the ages of 41 to 50 years of males with 23\%. In revised Garrick bibliographies (2017), we find that injury in sport in terms of anatomical location is the most common in the knees, then in the shoulders or other joint coinciding with our results, although the predominance is for the female due to theories such as anatomical differences, joint laxity, hormone levels, osteoporosis, etc., which predisposes to mechanical disorders of the joint, so they are the regions most affected, and more than the male ones.

According to Kellgren and Lawrence for radiological evaluation of the degree or scale of osteoarthritis, he obtained more that was in grade II or mild osteoarthritis and males aged 30 and 50 with 18 a41 a $15 \%$ respectively. Regarding graduate degrees of Arthrosis according to revised bibliographies we find no significant statistical differences of the degree s grad with respect to sexes, ages, anatomical location or other variables; author such as Alvarez et al. (2004), found that in retired athletes they have frequencies of radiological signs such as grade II and III of osteoarthritis, such as osteophytes and subchondral sclerosis, refers that sports in which repetitive movements are performed above the overuse shoulder of the joint and for a long time of execution, cause chronic degenerative lesions of these joint structures, microtraumas suffered by example pitchers in baseball, (pitcher), on, the other hand De Los Santos (2009), refers that they can present any degree of weed tortrosis the joint that is affected, this is expressed taking into account the characteristics of each sport, the time to practice them, the sports objects that they transport when they stand 
or those that condition these, being subjected to overloads, and sometimes excessive, etc., are conditioned on developing degenerative injury and evolving with varying degrees of osteoarthrosis.

Regarding the distribution for the classification to the sports group in which the athletes were grouped for the study, the males of the group of games with balls of 18 - 30 and 51 - 70 years predominated, and those of the male combat group of 18 at 30 with 15\% in each one respectively, the results coincide with the criterion De Los Santos (2009), refers that in sports where characteristics such as jumps in both defensive and offensive actions the knee joints as occurs in the jumper's knees in the ball player (volleyball, basketball, soccer player), which keep them in constant movement in different directions, while receiving continuously repeated microtraumas, and in sports in which the shoulder-humeral girdle generally those that occur during activities in which the arm is repeatedly raised above the head (volleyball player, baseball pitcher, javelin), combat (wrestlers) shoulders make them more vulnerable to these injuries. What has been said by the expert is supported, because due to the characteristics of the different sports groups (combat, fast strength, time and mark, ball games, and competitive art) it constitutes a problem of these injuries, especially for athletes of the high performance.

In the patients studied, the distribution for time of evolution of the degenerative disease, it was found that the predominance was in those who reported more than a year with the manifestation of the symptoms of the condition, mainly males aged 41 to 50 years with a $23 \%$, regarding the evolution of the disease, refer that degenerative injuries in sports due to osteoarthrosis are among the chronic injuries that develop and manifest over a long time; that a joint such as that of the shoulder is unstable due to its anatomy, where injuries present in it, even when minimal, often delay rehabilitation; Knee and shoulder injuries are quite complex in their treatment, sometimes requiring surgery to repair them, this leads to athletes having to spend more than a year away from their sports activities.

The prevalence of overuse of the joint was obtained in the study as the incidence factor for the appearance of the degenerative lesion, being in males from 41 to 50 years with $31 \%$ the most affected, the results coincide with bibliographic references (Álvarez et al., 2004; Garrick, 2017), where we found that around 60\% of injuries in sport correspond to the soft tissues of the osteomyoarticular system and these, between 40 and $50 \%$ are caused by trauma repeated by the overuse of sport (repetitive microtrauma), during training and competition events, finally, the consequence is premature wear of the components of the osteomyoarticular system, conditioning the appearance of degenerative disease such as osteoarthrosis, (race, sex or social stratum are not specified ). Kelly (2008), states that the highest risk of osteoarthritis in those high impact, repetitive sports, observed that osteoarthrosis was caused by repeated loads or by a specific traumatic event.

\section{As a regenerative medicine treatment, the most used cell therapy in the population of athletes treated was PRP}

As the cell therapy of the most widely used regenerative medicine, the use of PRP predominated, and it was mainly applied in males aged 18-30, 41-50, and 51-70 years of age. Hernández \& Anillo (2016) report that the use of both stem cells and platelets have shown promising results in traumatic and orthopedic disorders. The similarity of some of these alterations with those attended by sports doctors in athletes with injuries secondary to their training or competition, made these procedures create good prospects in sports medicine, they could also be of great benefit in the treatment of injured athletes. We obtained greater application with the PRP due to the greater ease of obtaining it concerning the CMN-SP, especially for patients' ex-athletes of middle age, these being the ones with the greatest number in the participation of the research.

PRP was also the most widely used as an option for another cycle or new treatment after the year of the previous treatment such as reimplantation, in which they showed evidence of partial favorable results achieved or loss of what was achieved, predominantly in women between 41 and 50 years old with the $15 \%$. In the bibliographies consulted we did not find statistical references between the variables.

Table 1

Distribution of patients according to general demographic variables. $\mathrm{N}=13$

\begin{tabular}{ccccccccccc}
\hline \multirow{2}{*}{$\begin{array}{c}\text { General data } \\
\text { of interest }\end{array}$} & \multicolumn{2}{c}{$18-30$} & \multicolumn{2}{c}{$31-40$} & \multicolumn{2}{c}{$41-50$} & \multicolumn{2}{c}{$51-70$} & \multicolumn{2}{c}{ TOTAL } \\
\cline { 2 - 10 } & $\mathrm{F}$ & $\mathrm{M}$ & $\mathrm{F}$ & $\mathrm{M}$ & $\mathrm{F}$ & $\mathrm{M}$ & $\mathrm{F}$ & $\mathrm{M}$ & $\mathrm{F}$ & $\mathrm{M}$ \\
\cline { 2 - 11 } & $\mathbf{\%}$ & $\mathbf{\%}$ & $\mathbf{\%}$ & $\mathbf{\%}$ & $\mathbf{\%}$ & $\mathbf{\%}$ & $\mathbf{\%}$ & $\mathbf{\%}$ & $\mathbf{\%}$ & $\mathbf{\%}$ \\
\hline
\end{tabular}

Vidal, V. R., Pérez, N. A. A., Rodríguez, R. J. R., \& Munive, K. L. (2020). Demography of degenerative arthropathy and regenerative medicine in santiaguero sport. International Journal of Health Sciences, 4(3), 20-31. https://doi.org/10.29332/ijhs.v4n3.457 


\begin{tabular}{|c|c|c|c|c|c|c|c|c|c|c|c|}
\hline \multirow[b]{2}{*}{$\begin{array}{l}\text { Patient } \\
\text { group }\end{array}$} & Athletes & 0 & 23 & 0 & 7.6 & 0 & 0 & 7.6 & 0 & 7.6 & 31 \\
\hline & $\begin{array}{l}\text { Former } \\
\text { athletes }\end{array}$ & 0 & 7.6 & 0 & 0 & 15 & 23 & 7.6 & 7.6 & 23 & 38 \\
\hline \multirow{3}{*}{$\begin{array}{l}\text { Locate. } \\
\text { anatomical }\end{array}$} & Shoulders & 0 & 15 & 0 & 7.6 & 0 & 0 & 15 & 0 & 15 & 23 \\
\hline & Knees & 0 & 15 & 0 & 0 & 15 & 23 & 0 & 7.6 & 15 & 46 \\
\hline & I & 0 & 15 & 0 & 0 & 0 & 0 & 0 & 0 & 0 & 15 \\
\hline \multirow{3}{*}{$\begin{array}{l}\text { Degree of } \\
\text { Arthrosis }\end{array}$} & II & 0 & 15 & 0 & 7.6 & 15 & 15 & 7.6 & 7.6 & 23 & 46 \\
\hline & III & 0 & 0 & 0 & 0 & 0 & 7.6 & 0 & 7.6 & 0 & 15 \\
\hline & IV & 0 & 0 & 0 & 0 & 0 & 0 & 0 & 0 & 0 & 0 \\
\hline \multirow{5}{*}{$\begin{array}{l}\text { Sports } \\
\text { group }\end{array}$} & Combat & 0 & 15 & 0 & 7.6 & 0 & 7.6 & 0 & 7.6 & 0 & 38 \\
\hline & $\begin{array}{l}\text { Fast } \\
\text { forcea }\end{array}$ & 0 & 0 & 0 & 0 & 0 & 0 & 0 & 0 & 0 & 0 \\
\hline & $\begin{array}{l}\text { Time and } \\
\text { brand }\end{array}$ & 0 & 0 & 0 & 0 & 0 & 7.6 & 0 & 0 & 0 & 7.6 \\
\hline & $\begin{array}{l}\text { Games } \\
\text { with balls }\end{array}$ & 0 & 15 & 0 & 0 & 7.6 & 7.6 & 15 & 0 & 23 & 23 \\
\hline & $\begin{array}{l}\text { Competiti } \\
\text { ve art }\end{array}$ & 0 & 0 & 0 & 0 & 7.6 & 0 & 0 & 0 & 0 & 7.6 \\
\hline \multirow{4}{*}{$\begin{array}{l}\text { Time for } \\
\text { the } \\
\text { evolution of } \\
\text { the disease }\end{array}$} & $\begin{array}{l}<3 \\
\text { months }\end{array}$ & 0 & 0 & 0 & 0 & 0 & 0 & 0 & 0 & 0 & 0 \\
\hline & $\begin{array}{l}4 \text { a } 6 \\
\text { Months }\end{array}$ & 0 & 23 & 0 & 0 & 0 & 0 & 0 & 0 & 0 & 23 \\
\hline & 7 a 1year & 0 & 0 & 7.6 & 0 & 15 & 0 & 0 & 0 & 23 & 0 \\
\hline & $>1$ year & 0 & 7.6 & 0 & 0 & 0 & 23 & 15 & 7.6 & 15 & 38 \\
\hline \multirow{4}{*}{$\begin{array}{l}\text { Incident } \\
\text { factors } \\
\text { on the } \\
\text { onset of } \\
\text { injury }\end{array}$} & Overuse & 0 & 0 & 0 & 0 & 0 & 31 & 0 & 0 & 0 & 31 \\
\hline & $\begin{array}{l}\text { Sports } \\
\text { acute } \\
\text { trauma }\end{array}$ & 0 & 0 & 0 & 0 & 0 & 0 & 0 & 23 & 0 & 23 \\
\hline & Overload & 0 & 15 & 0 & 7.6 & 0 & 0 & 0 & 0 & 0 & 23 \\
\hline & $\begin{array}{l}\text { Previous } \\
\text { injury }\end{array}$ & 0 & 7.6 & 0 & 0 & 0 & 0 & 0 & 15 & 0 & 23 \\
\hline \multirow{2}{*}{$\begin{array}{l}\text { Medicine } \\
\text { regenerate } \\
\text { implant. }\end{array}$} & PRP & 0 & 23 & 0 & 0 & 15 & 23 & 7.6 & 0 & 23 & 46 \\
\hline & CMN - SP & 0 & 7.6 & 0 & 0 & 0 & 15 & 0 & 7.6 & 0 & 46 \\
\hline \multirow{2}{*}{$\begin{array}{l}\text { Reimplanta } \\
\text { tion a year } \\
\text { post- } \\
\text { implant }\end{array}$} & PRP & 0 & 7.6 & 0 & 7.6 & 15 & 0 & 0 & 0 & 15 & 15 \\
\hline & CMN - SP & 0 & 0 & 0 & 7.6 & 0 & 0 & 0 & 0 & 0 & 7.6 \\
\hline
\end{tabular}

Source: patient medical history.

Legend: F: female. M: male. N: total treated patients. PRP: platelet-rich plasma. CMN- SP:s single-nuclear cell of peripheral blood.

Table 2, the distribution of patients according to particular demographic variables of interest location of the athlete's and former athlete's population when the injury occurs.

In the particular variable location of the athlete and former athlete when the injury occurs, it was obtained for the group of former athletes the predominance during their active sports life in training with $23 \%$, and inactive high-performance athletes, it was obtained a Similar result of $7.6 \%$ for all locations in the distribution when the injury occurs. In a bibliographic review carried out by Kelly (2008), where he describes in his article "Incidence of Injuries and Diseases in Retired Athletes" together with other authors, that the practice of nonelite sports and the performance of moderate exercises do not imply A risk to develop these injuries, that is to 
say, those that are carried out recreationally implies a small risk, but it is the extreme training that predisposes to the injury; On the other hand, as life progresses, it usually progresses to problems, such as instability of the knees, torn menisci, damage to the cartilage with osteoarthrosis of the knees or other joints.

Sports that involve overhead throwing are frequent with high doses of local stress, where athletes who trained with throwing weights greater than $3 \mathrm{~kg}$ had a significantly higher risk of presenting degenerative changes in the shoulders than javelin throwers who they did not do these training. According to the authors, the probability of being in extreme training in athletes the highest incidence for the location of the appearance of these injuries is deduced, coinciding with our results.

Tabla 2

Distribución de pacientes según variables particulares. Ubicación del atleta y ex atleta cuando ocurre la lesión $\mathrm{N}=13$

\begin{tabular}{|c|c|c|c|c|c|c|c|c|c|}
\hline & $\begin{array}{c}\text { Training } \\
\text { Buffers } \\
\quad \% \\
\end{array}$ & $\begin{array}{c}\text { Stops } \\
\text { Provincial } \\
\text { Games } \\
\mathbf{0} \\
\end{array}$ & $\begin{array}{l}\text { National } \\
\text { Games } \\
\text { \% }\end{array}$ & $\begin{array}{l}\text { Pan } \\
\text { American } \\
\text { Games } \\
\quad \% \\
\end{array}$ & $\begin{array}{l}\text { Games } \\
\text { Olympics } \\
\quad \% \\
\end{array}$ & $\begin{array}{l}\text { Foreign } \\
\text { hiring } \\
\quad \% \\
\end{array}$ & $\begin{array}{c}\text { Detraining } \\
\\
\quad \% \\
\end{array}$ & Others & $\begin{array}{r}\text { TOTAL } \\
\\
\% \\
\end{array}$ \\
\hline \multicolumn{10}{|l|}{$\begin{array}{c}\text { HIGH } \\
\text { PERFORMANCE } \\
\text { (ATHLETES) }\end{array}$} \\
\hline EIDE & 0 & 0 & 0 & 0 & 0 & 0 & 0 & 0 & 0 \\
\hline Academy & 7.6 & 0 & 0 & 0 & 0 & 0 & 0 & 0 & 7.6 \\
\hline $\begin{array}{l}\text { Pre national } \\
\text { team }\end{array}$ & 0 & 7.6 & 0 & 0 & 0 & 0 & 0 & 0 & 7.6 \\
\hline $\begin{array}{l}\text { Selection } \\
\text { national }\end{array}$ & 0 & 0 & 7.6 & 0 & 0 & 0 & 0 & 0 & 7.6 \\
\hline Sports combined & 0 & 0 & 0 & 0 & 0 & 7.6 & 0 & 0 & 7.6 \\
\hline $\begin{array}{l}\text { University of } \\
\text { Physical Culture } \\
\text { (FORMER } \\
\text { ATHLETES) }\end{array}$ & 0 & 0 & 0 & 0 & 0 & 0 & 0 & 7.6 & 7.6 \\
\hline $\begin{array}{l}\text { During life } \\
\text { active sports }\end{array}$ & 23 & 0 & 7.6 & 0 & 0 & 0 & 0 & 7.6 & 38 \\
\hline $\begin{array}{l}\text { Post Active } \\
\text { Sports Life }\end{array}$ & 0 & 0 & 0 & 0 & 0 & 0 & 7.6 & 15.3 & 23 \\
\hline
\end{tabular}

Source: a clinical history of patients.

Legend: EIDE: sports initiation school. N: total of patients treated.

Table 3. The distribution of patients according to particular demographic variables of interest is observed in the training cycle in which the injury occurs. $\mathrm{N}=13$.

In the particular variable of the athlete and former athlete training cycle in which the injury occurs, the predominance in the 1st stage or general stage was observed in the group of former athletes during their active sports life, and the predominance in the 3rd stage, of it the competitive one in the group of athletes, with 23\% equally for each one. Regarding our results consulted with other authors in reviewed bibliographies, we have not found extensive statistical references between the variables of the stages of the training cycle and the occurrence of this degenerative lesion. However, authors such as De Los Santo (2009), argue that sports injuries are varied ways that the athlete's body can be affected in a sports discipline during the different stages of the macro-cycle of training or its fundamental competition. Kelly (2008), together with other authors, describe that sports competitions make a person compete, often with inadequate recovery, and injured, thus producing a higher rate of knee replacement, mainly due to severe degenerative causes (Berengüí et al., 2013).

Vidal, V. R., Pérez, N. A. A., Rodríguez, R. J. R., \& Munive, K. L. (2020). Demography of degenerative arthropathy and regenerative medicine in santiaguero sport. International Journal of Health Sciences, 4(3), $20-31$. https://doi.org/10.29332/ijhs.v4n3.457 
It also describes among other authors that in studies collected from a database of follow-up to injuries in university athletes according to the respective sports and by universities, it was possible to determine the total percentage of injuries that occur in practices and those that occur in matches or competitions, where studies carried out on gymnastics, volleyball, basketball, soccer, found injuries that occurred during practice, had a higher percentage than those that occurred during games or competitions, however in softball and baseball injuries occurred during Matches were significantly higher, produced by receiving blows with the ball, or by making contact with another player, situations that are very rarely observed in practice.

The results are important because the number of practices in each sport is much higher than the number of games, which coincide with our results in the predominance of former athletes during their active sports life in the cycle of the 1st stage or stage of general physical preparation, being in this period of the cycle in which more sports are practiced, with the greatest amount of load possible for the athlete, and greater volumes of force and aerobic and anaerobic resistance, which can, in turn, give rise to the lesions.

Table 3

Distribution of patients according to particular variables. The training cycle in which the injury occurs. $\mathrm{N}=13$

\begin{tabular}{|c|c|c|c|c|c|c|c|}
\hline & $\begin{array}{c}\text { 1st stage } \\
\text { (General) } \\
\%\end{array}$ & $\begin{array}{c}\text { 2nd stage } \\
\text { (Special) } \\
\%\end{array}$ & $\begin{array}{l}\text { Pre } \\
\text { Competitive } \\
\%\end{array}$ & $\begin{array}{c}\text { 3rd stage } \\
\text { Competitiva } \\
0\end{array}$ & $\begin{array}{c}\text { Transito } \\
\%\end{array}$ & $\begin{array}{c}\text { Not } \\
\text { cycles } \\
0\end{array}$ & TOTAL \\
\hline $\begin{array}{l}\text { Athlete } \\
\text { Former } \\
\text { athletes }\end{array}$ & 7.6 & 0 & 0 & 23 & 0 & 7.6 & 38 \\
\hline $\begin{array}{l}\text { during } \\
\text { active sport } \\
\text { life } \\
\text { Former } \\
\text { athletes }\end{array}$ & 23 & 0 & 0 & 7.6 & 0 & 7.6 & 38 \\
\hline $\begin{array}{l}\text { post active } \\
\text { life } \\
\text { sporty }\end{array}$ & 0 & 0 & 0 & 0 & 0 & 23 & 23 \\
\hline TOTAL & 23 & 0 & 0 & 30.7 & 0 & 46.1 & 100 \\
\hline
\end{tabular}

Source: a clinical history of patients. N: a total of patients treated

Concerning PRP as the cell therapy of the major regenerative medicine used, it was not possible to perform comparative evaluations that could associate, coincide or differentiate the prevalence of its use, since in consulted bibliographies we have found that both stem cells and platelets have been widely used in degenerative diseases, and of them in osteoarthrosis, in our research, its greatest use was given in the ease of obtaining it, especially in middle-aged patients who were mostly treated, as well as how we do not agree on how much to the predominance of sex and degenerative disease, since in the consulted bibliographies these report a higher frequency of the disease in females. According to the results obtained, we consider that it is necessary to carry out more research, linking degenerative injuries and other injuries in the sport with the variables studied in groups of sports populations.

\section{Conclusion}

At the end of the research, the study of the general and particular demographic variables of interest was effective, we obtained results that allowed us to associate, coincide and differentiate with statistical results from other authors in consulted bibliographies. We found a coincidence for the degenerative lesion due to osteoarthrosis in the variables studied in terms of the predominance of the most affected anatomical region of the knees; the factor of incidence for the appearance of the disease the overuse of the joint; the time of evolution of the degenerative disease in those older than the year of evolution with the manifestation of 
symptoms, the most frequent grade II osteoarthritis in middle-aged and former athletes or retired athletes; Ball games are often the most affected by this injury, the location of the athlete for the occurrence of the injury are more frequent in training, and training cycles for the occurrence of the injury, the 1st stage or stage of physical preparation was the most frequent, bought from those that occurred during the competitive stage in matches or competitions.

Acknowledgments

We are grateful to two anonymous reviewers for their valuable comments on the earlier version of this paper.

Vidal, V. R., Pérez, N. A. A., Rodríguez, R. J. R., \& Munive, K. L. (2020). Demography of degenerative arthropathy and regenerative medicine in santiaguero sport. International Journal of Health Sciences, 4(3), 20-31. https://doi.org/10.29332/ijhs.v4n3.457 


\section{References}

Abad, L. N., Vidal, V. R., \& Sabatés, H. R. R. (2020). Gonoarthrosis in former athletes treated which regenerative therapy and therapeutic exercise program. International journal of health sciences, 4(2), 1-9.

Ahern, D. K., \& Lohr, B. A. (1997). Psychosocial factors in sports injury rehabilitation. Clinics in sports medicine, 16(4), 755-768. https://doi.org/10.1016/S0278-5919(05)70052-1

Ali Pérez, NA, Robinson Rodríguez, RJ, \& Hernández Ramírez, P. (2019). New health technology for the development of regenerative medicine in Santiago de Cuba. Cuban Journal of Hematology, Immunology and Hemotherapy, 35 (3).

Álvarez Cambras A, Jacobo Núñez M, Marrero Riverón LO,, Castro Soto del Valle A. (2014). Lesiones de partes blandas en atletas de alto rendimiento. Rev Cubana Ortop Traumatol Vol. 18(2).

Álvarez Cambras, R., Jacobo Núñez, ME, Marrero Riverón, LO, \& Castro Soto del Valle, A. (2004). Soft tissue injuries in high performance athletes. Cuban Journal of Orthopedics and Traumatology , 18 (2), 0-0.

Berengüí-Gil, R., de Los Fayos, E. J. G., \& Hidalgo-Montesinos, M. D. (2013). Características psicológicas asociadas a la incidencia de lesiones en deportistas de modalidades individuales. Anales de Psicología/Annals of Psychology, 29(3), 674-684.

Cuba Ministerio de Salud Pública. (2012). Resolución ministerial No. 632;

De los Santo, F. (2009). Eficacia de la Laserterapia de media potencia en las lesiones de partes blandas de la articulación del tobillo, en la comunidad deportiva de la ESFAR "lsrael Reyes Zayas" [Tesis Maestría]. Santiago de Cuba: Instituto Superior de Cultura Física. Facultad Santiago de Cuba. "Manuel Fajardo Rivero".

Figueroa, RM, Figueroa, CM, Rodriguez, RC, \& Poblete, DF (2015). Osteoarthritis (osteoarthritis) of the knee. Chilean Journal of Orthopedics and Traumatology, 56 (3), 45-51. https://doi.org/10.1016/j.rchot.2015.10.005

Finch, C. (2006). A new framework for research leading to sports injury prevention. Journal of science and medicine in sport, 9(1-2), 3-9. https://doi.org/10.1016/j.jsams.2006.02.009

Friery, K. (2008). Incidence of Injuries and Illnesses in Retired Athletes: A Review-G-SE / Editorial Board / Dept. Content. PubliCE.

Garrick, N. (2017). Lesiones deportivas. National Institute of Arthritis and Musculoskeletal and Skin Diseases.

Hernández-Hernández, A., \& Anillo-Badía, R. (2016). Regenerative medicine and sports medicine, a fruitful integration: introduction and advances in Cuba. Cuban Journal of Hematology, Immunology and Hemotherapy, 32 (3), 285-288.

Kellgren, J. H., \& Lawrence, J. S. (1957). Radiological evaluation of osteoarthritis. Ann. Rheum. Dis, 16(4), 494501.

Kuttner, K., \& Goldberg, V. M. (1995). Osteoarthritis disorders Rosemout. In American Academy of, Orthopedic Surgeons (pp. 21-25).

Martínez Estupiñán, L. (2017). Sports injuries in child athletes. Twenty year study. MediSur , 15 (6), 819-825.

Rhee, Y. G., Lee, D. H., Chun, I. H., \& Bae, S. C. (2004). Glenohumeral arthropathy after arthroscopic anterior shoulder stabilization. Arthroscopy: The Journal of Arthroscopic \& Related Surgery, 20(4), 402-406. https://doi.org/10.1016/j.arthro.2004.01.027

Zuckerman, J. D., Scott, A. J., \& Gallagher, M. A. (2000). Hemiarthroplasty for cuff tear arthropathy. Journal of shoulder and elbow surgery, 9(3), 169-172. https://doi.org/10.1067/mse.2000.105138 


\section{Biography of Authors}

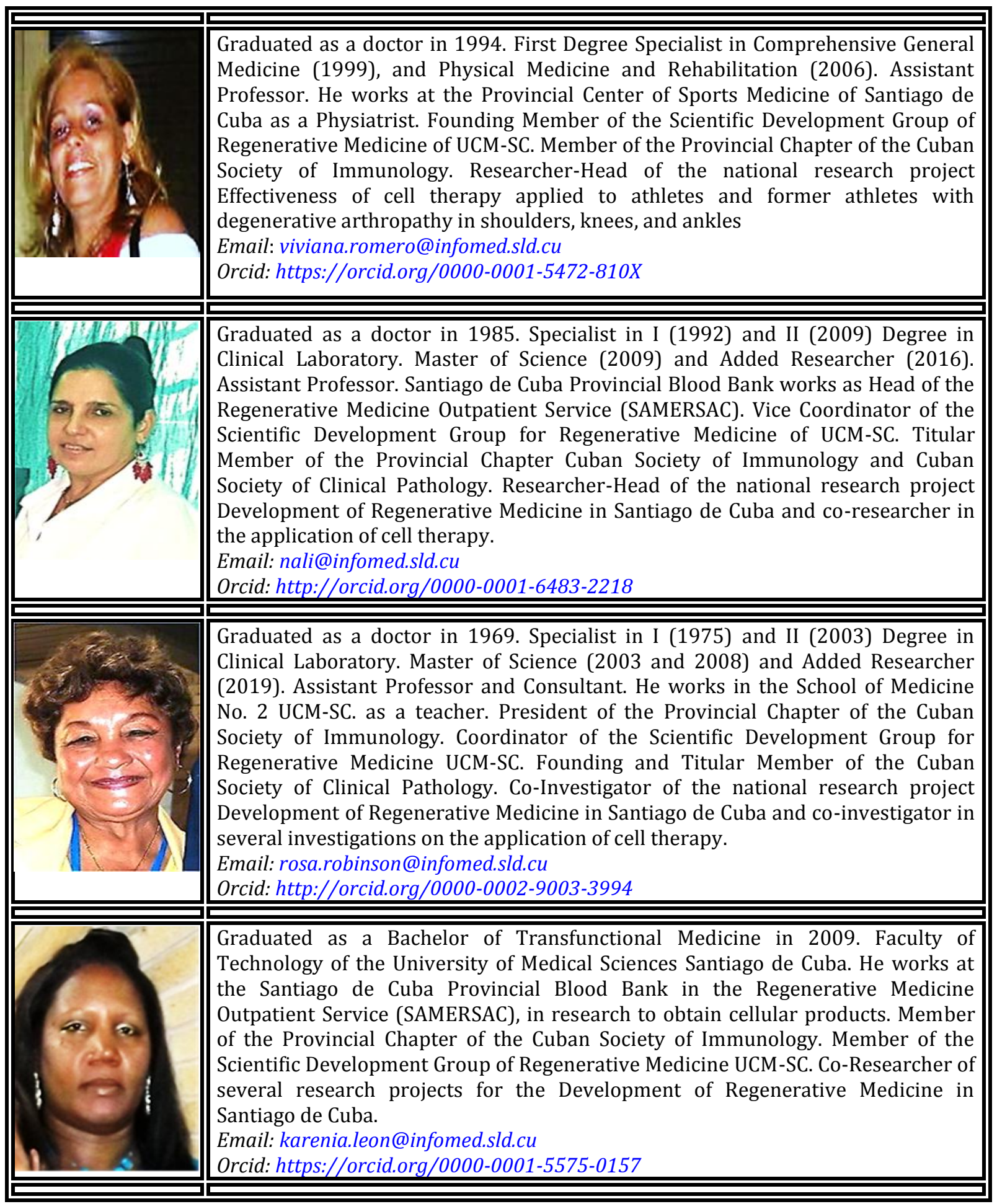

Vidal, V. R., Pérez, N. A. A., Rodríguez, R. J. R., \& Munive, K. L. (2020). Demography of degenerative arthropathy and regenerative medicine in santiaguero sport. International Journal of Health Sciences, 4(3), $20-31$. https://doi.org/10.29332/ijhs.v4n3.457 